\title{
Sufism in the West
}

Jamal Malik and John Hinnells, eds. New York: Routledge, 2006. 207 pages.

This edited volume, along with David Westerlund's edited Sufism in Europe and North America (RoutledgeCurzon: 2004), are pioneering works, since the systematic study of this topic is still in its infancy. Its introduction and nine chapters bring together anthropological, historical, Islamicist, and sociological perspectives on questions of identity as regards Sufism's double marginalization within a non-Muslim majority environment and within the broader Islamic discourse. The Sufis' need to position themselves against and reconcile themselves with a variety of others causes western Sufis to employ a fascinating kaleidoscope of strategies ranging from assimilation to confrontation and appropriation.

Jamal Malik's introduction surveys Islamic mysticism and the "major themes of diasporic Sufism" (pp. 20-25). He presents the complex interrelatedness of ethnic, cultural, religious, and generational identities and addresses important issues concerning representation, knowledge production, and adaptation. His conclusion that "Sufism - intellectually as well as sociologically - may eventually become mainstream Islam itself due to its versatile potential, especially in the wake of what has been called the failure of political Islam worldwide" (p. 25), however, is rather bold. Nevertheless, as Ron Geaves shows, one has to acknowledge that, at least in Great Britain and the United States, Sufis have begun to confront antiSufi rhetoric more openly. He describes Sufi-Muslim attempts to monopolize the term ahl al-sunnah wa al-jam 'ah (people of the tradition and the 
community) as neo-Sufi revivalism, namely, as a claim for reestablishing Sufism in terms of Sunni traditionalism as the center of Islamic faith and practice. It certainly is remarkable when "the shaykhs are beginning to successfully argue that it is their 'aqida which is the norm of Islam, and it is the Wahhabi/Salafi critique that is the aberration from traditional belief and practice" (p. 156).

The question remains, however, to what extent such examples represent a new trend in terms of a global Sufi revival. Pnina Werbner focuses on British Sufis and compares the styles, activities, and interpretations of Sufism by three khalifas of the Pakistani Naqshbandi sheikh Zindapir (d. 1999). Her ethnography uncovers the extent to which these leaders' individual styles impact local formulations of Sufism, especially in the diaspora, where immigrant Muslims must accommodate heterogeneous norms and lifestyles that influence organizational forms and cultural practices.

Gerdien Jonker classifies Germany's Turkish Sulaymanci movement, named after Naqshbandi-Khalidi sheikh Süleyman Tunahan (d.1959), as a "Sufi lay communit[y], holding on to Sufi devotion while refocusing on worldly religious aims" (p. 71). While maintaining such Sufi practices as dhikr and imitatio Muhammadi, as well as a centralized and hierarchical organization, the group has no sheikh and considers itself a da $w a h$ organization dedicated to individual salvation and strengthening the Islamic community within a revivalist framework. Jonker interprets this in terms of a process of adaptation, first, to Turkey's laicist context and, second, to Germany's secular context, in which pressures to assimilate and the fear of losing one's identity render Turkish immigrants receptive to the rhetoric of religious revival.

The importance of comparative works on Sufi communities should be evident, given Sufism's transnational character. A case in point is Jorgen Nielsen, Mustafa Draper, and Galina Yemelianova's joint article on the HaqqaniNaqshbandiyya. Comparing Haqqani circles in Great Britain, Lebanon, and Dagestan, the authors show how local conditions shape the particular circles and how independent they are from each other. Despite the shared reverence for the current sheikh, Turkish Cypriote Nazim al-Haqqani, the group's many quarrels and splits led the authors to state that "the tariqa only fully exists where Shaikh Nazim is" (p. 113). Investigating the localities of Haqqani practice also reveals discrepancies with the tariqa's extensive selfrepresentation on the Internet. This calls into serious question the use of Internet sources for research on Sufi communities in the absence of any accompanying fieldwork. 
Leonard Lewisohn assesses the Iranian Shi ite Ni`matu'llahi order's history and organization in the West. His comparison of its Iranian and western practices reveals an extreme adaptability to new cultural environments. In the diaspora, more emphasis is placed on nationalist Iranian conceptions of Sufism's origins, which he calls "the Persianization of Sufism" (p. 58), while the Shari ah's importance has declined considerably. Appropriating the modernist discourses of nationalism and secularism certainly eases adaptation to non-Muslim environments.

Three contributions focus on Sufism in the United States. Marcia Hermansen develops a typology of the "[1]iterary productions of Western Sufi movements," namely, English Sufi literature written for a largely western audience. She discusses differences in literary genres (ranging from transcribed lectures to hagiographic materials) and analyzes their dominant motifs. Remarking that the "presence of Western Sufis in the academic Study of Islam" would sometimes result in blurred boundaries "between an academic study or textbook and an exposition of Sufism as the truth," she alludes to interesting questions regarding the relationship between insider and outsider perspectives (p. 43).

Gisela Webb describes how the Bawa Muhaiyaddeen Fellowship, over the last three decades, has gone from being a guru movement with Sufi elements to becoming a community that is more self-conscious of Islamic symbolisms and practices. She sees this transformation as reflecting the larger conversion process of American spiritual seekers toward Islam leading to an increased intermingling between immigrant and converted Muslims. As she shows, the Fellowship has remained open to both non-Muslim and Muslim Sufis, an interesting and rather exceptional phenomenon in its own right.

This volume delivers fascinating insights into the construction and uprooting of such binaries as local/global, orthodox/heterodox, and insider/ outsider positions. It thus reveals the hybrid character of Sufism in the West. The high quality and originality of most of the articles make this volume a must for everybody interested in Sufism in the West and highly recommended for students of Islam in the West. The modes of cultural as well as religious adaptation and appropriation employed by Sufi-Muslim communities in the West to survive and prosper make it, moreover, an insightful source for anyone interested in religious and ethnic responses to migration and diaspora experiences. 